\title{
Perbandingan Status Nutrisi Minggu Pertama pada Pasien Pascacedera Otak Traumatik Sedang dan Berat yang Dirawat di RSUP Dr. Hasan Sadikin Bandung Dinilai dengan Subjective Global Assessment (SGA)
}

\author{
Tengku Addi Saputra, Dewi Yulianti Bisri, Tatang Bisri \\ Departemen Anestesiologi dan Terapi Intensif \\ Fakultas Kedokteran Universitas Padjadjaran-RSUP Dr. Hasan Sadikin Bandung
}

\begin{abstract}
Abstrak
Latar Belakang dan Tujuan: Penilaian status nutrisi merupakan hal vital untuk menentukan rencana pemberian nutrisi dan memperbaiki luaran pasien dengan cedera otak traumatik (COT). Pada pasien COT terjadi hipermetabolisme, hiperkatabolisme, dan intoleransi glukosa yang dapat mempengaruhi luaran pasien. Penilaian status gizi dilakukan dengan Subjective Global Assessment (SGA). Tujuan penelitian ini adalah untuk membandingkan status nutrisi antara pasien COT sedang dan berat yang dinilai dengan SGA. Subjek dan Metode: Penelitian observasional analitik cross sectional ini dilakukan pada 22 pasien COT yang dirawat di RSUP Dr Hasan Sadikin Bandung sejak November 2016 - Juli 2017, yang dibagi menjadi 2 kelompok, yaitu COT sedang dan berat. Status nutrisi subjek penelitian dinilai dengan SGA selama 7 hari. Analisis data dilakukan dengan Chi Square, Kolmogorof-Smirnof dan Exact Fisher.

Hasil: Terdapat perbedaan status nutrisi yang signifikan antara kelompok COT sedang dan berat pada hari perawatan ke-6 dan 7, dimana lebih banyak didapatkan malnutrisi berat pada kelompok COT berat $(\mathrm{p}<0,05)$.

Simpulan: Pada penelitian ini malnutrisi lebih banyak terjadi pada pasien dengan COT berat, disebabkan oleh perlambatan pemberian nutrisi akibat disfungsi gastrointestinal yang terjadi pada pasien COT berat sehingga diperlukan strategi pemberian nutrisi khusus pada kelompok COT berat.
\end{abstract}

Kata kunci: cedera otak traumatik, SGA, status nutrisi

JNI 2018;7(3): 134-

\section{Comparison of a One Week Nutritional Status between Moderate and Severe Traumatic Brain Injury Patient in Dr. Hasan Sadikin General Hospital Assessed with Subjective Global Assessment (SGA)}

\begin{abstract}
Background and Objective: Assessment of nutritional status is vital in determining nutritional plans and improving outcomes of traumatic brain injury (TBI) patients. Hypermetabolism, hypercatabolism, and glucose intolerance occur in patients with TBI can affect its outcome. The used nutritional status assessment is Subjective Global Assessment (SGA). The aim of this study was to compare nutritional status in moderate and severe TBI patients assesed with SGA. Subject and Method: This cross sectional observational analytic study was conducted on 22 TBI patients treated in RSUP DR. Hasan Sadikin Bandung since November 2016 - July 2017, divided into 2 groups, moderate and severe TBI. Assessment of SGA in study subjects was conducted for 7 days. Data was analyzed with Chi Square, Kolmogorof-Smirnof and Exact Fisher test.

Results: This study showed a significant difference in nutritional status between moderate and severe TBI groups during the 6th and 7th treatment days, whereas more severe malnutrition was found in the severe TBI group ( $<<0.05)$. Conclusion: Compares to patients with moderate TBI, malnutrition is more prevalent in patients with severe TBI, because of delayed of nutrient delivery due to gastrointestinal dysfunction occurring in severe TBI patients requiring specific nutritional strategies in severe TBI group.
\end{abstract}

Key words: traumatic brain injury, SGA, nutritional status

JNI 2018;7(3): 134- 


\section{Pendahuluan}

Nutrisi merupakan aspek penting pada penatalaksanaan pasien kritis dengan cedera otak traumatik (COT) namun seringkali tidak menjadi prioritas. Pemberian nutrisi perlu dilakukan sesegera mungkin setelah kondisi pasien stabil dan pemberian terapi. Dukungan nutrisi yang tepat akan meningkatkan luaran pasien. Sebuah rekomendasi berdasarkan Bendo, menyarankan pasien harus diberikan nutrisi penuh dalam 7 hari setelah trauma. ${ }^{1-3}$ Perubahan metabolisme yang terjadi pada COT yaitu hipermetabolik dan katabolik yang meningkatkan kebutuhan energi sistemik dan serebral serta mempengaruhi homeostasis nitrogen. ${ }^{1,-6}$ Bila disertai dengan imobilitas, hiperkatabolisme akan meningkatkan risiko malnutrisi. ${ }^{7}$ Pasien COT memiliki risiko malnutrisi, imunokompromais, dan penyembuhan yang lambat bila kebutuhan nutrisi terutama protein tidak terpenuhi. ${ }^{2}$ Malnutrisi dilaporkan mempengaruhi morbiditas dan mortalitas pasien $\mathrm{COT}^{3,6}$

Monitoring status nutrisi pada pasien COT merupakan hal penting karena dapat menjadi panduan manajemen nutrisi yang lebih baik.4 Penilaian status nutrisi dilakukan dengan Subjective Global Assessment (SGA) yaitu alat penilaian nutrisi yang didesain oleh Baker, dkk pada tahun 1982 untuk mengidentifikasi risiko luaran yang buruk berhubungan dengan status nutrisi yang lebih buruk pada pasien surgikal. Subjective Global Assessment (SGA) terdiri dari kuesioner yang menanyakan riwayat klinis dan pemeriksaan fisik kemudian pasien dikelompokkan menjadi ternutrisi normal (A), cukup atau dicurigai malnutrisi (B) atau malnutrisi berat $(\mathrm{C}) .{ }^{8,9}$

Subjective Global Assessment (SGA) memberikan gambaran yang sama atau lebih baik dari metode penilaian lain seperti antropometri dan data laboratorium. Subjective Global Assessment (SGA) juga dikatakan dapat mendeteksi malnutrisi secara dini. ${ }^{9}$ Penelitian mengemukakan bahwa pasien COT akan dapat kehilangan berat badan $15 \%$ per minggu. 6 Selain itu, sekitar $68 \%$ pasien dengan COT menunjukkan tanda malnutrisi dalam 2 bulan setelah trauma. Penelitian lain menyatakan rendahnya nilai Glasgow Outcome Scale (GOS) 6 bulan setelah COT pada pasien dengan malnutrisi. ${ }^{710}$ Penelitian di India terhadap 88 pasien dengan COT berat $(\mathrm{GCS}<8)$ menggambarkan peningkatan progresif prevalensi malnutrisi pada pasien yang dirawat dengan COT berat dan 75\% terjadi dalam 3 minggu. Adanya tanda klinis malnutrisi berhubungan dengan luaran yang buruk dalam 6 bulan setelah COT. ${ }^{10}$ Penelitian lain di Boston terhadap 1.685 pasien dengan COT yang mendapatkan perawatan di ICU antara tahun 1997 dan 2011 menyatakan bahwa pasien dengan malnutrisi memiliki risiko mortalitas dalam 30 hari 1,7 kali lebih tinggi dan mortalitas dalam 90 hari 1,9 kali lebih tinggi dibandingkan dengan pasien tanpa malnutrisi $(p<0,001)$. Pada pasien yang bertahan hingga keluar dari rumah sakit, terdapat peningkatan 50\% mortalitas 90 hari (p 0,059) dan 40\% mortalitas 365 hari setelah perawatan $(p=0,035)$ pada pasien yang dirawat di ICU dengan malnutrisi. ${ }^{4}$

Berbagai penelitian telah dilakukan untuk memonitor status nutrisi pada pasien dengan COT namun belum ada penelitian mengenai kondisi nutrisi pada pasien COT yang dirawat di RSUP Dr. Hasan Sadikin Bandung dengan penilaian SGA. Tujuan penelitian ini adalah untuk membandingkan status nutrisi antara pasien COT sedang dan berat di RSUP Dr. Hasan Sadikin dinilai dengan SGA.

\section{Subjek dan Metode}

Penelitian ini bersifat observasional analitik yang dilakukan pada 22 pasien dengan cedera otak traumatik (COT) sedang dan berat yang dirawat di RSUP Dr. Hasan Sadikin Bandung. Penelitian dilakukan pada bulan November 2016 - Juli 2017. Kriteria inklusi pada penelitian ini adalah pasien COT sedang dan berat $(\mathrm{GCS}<13$ ) pasca operasi yang di rawat di ruang intensif RSHS, usia 18 - 60 tahun. Kriteria eksklusi meliputi pasien dengan trauma di tempat lain, pasien memiliki penyakit metabolik sebelumnya. Pasien dikeluarkan dari penelitian bila pasien meninggal selama waktu pengambilan sampel. Perhitungan besar sampel dilakukan berdasarkan perhitungan 
statistik dengan menetapkan taraf kepercayaan 90\% dan kuasa uji (power test) 80\%. Dengan menggunakan rumus penentuan besar sampel untuk penelitian analitis kategorik numerik tidak berpasangan didapatkan jumlah sampel sebanyak 22 orang. Sampel dibagi berdasarkan GCS menjadi kelompok COT sedang (GCS 913) dan COT berat (GCS 3-8), masing-masing berjumlah 11 orang. Pengambilan sampel dengan consecutive sampling.

Setelahmendapatkan persetujuan dariKomite Etik dan Penelitian Kesehatan Fakultas Kedokteran Universitas Padjadjaran RSUP Dr. Hasan Sadikin Bandung, peserta penelitian dipilih berdasarkan kriteria inklusi dan eksklusi yang akan dilakukan informed consent mengenai penelitian yang dilaksanakan. Pencatatan awal pasien meliputi identitas, diagnosis, dan GCS saat pasien di ruang intensif pascaoperatif. Penilaian kondisi nutrisi dilakukan setiap hari dengan formulir SGA, dimulai dari pasien masuk hingga 7 hari pasien dirawat di RSUP Dr. Hasan Sadikin Bandung dan tidak ada intervensi perlakuan dari peneliti terhadap pasien sebagai subjek penelitian.

Prosedur pengukuran berat badan digunakan hospital bed elektrik dengan timbangan.
Pemberian nutrisi enteral pada hari perawatan ke dua. Analisis data untuk data kategorik diuji dengan uji Chi-Square, untuk data numerik dinilai dengan uji normalitas Shapiro Wilks test kemudian uji Mann Whitney. Uji Statistika untuk membandingkan karakteristik lebih dari dua kelompok berpasangan digunakan uji Repeated ANOVA. Kriteria kemaknaan yang digunakan adalah nilai $p$ apabila $p \leq 0,05$ artinya signifikan atau bermakna secara statistika. Data yang diperoleh dicatat dalam formulir khusus kemudian diolah melalui program Statistical Product \& Service Solution (SPSS) versi 21.0 for Windows.

\section{Hasil}

Penelitian dilakukan pada 22 pasien dengan COT sedang (GCS 9-13) dan berat (GCS 3-8) yang dibagi menjadi 2 kelompok berdasarkan GCS masing-masing 11 orang yang diambil berdasarkan consecutive sampling. Kedua kelompok memiliki usia, body mass index (BMI), dan diagnosa yang tidak berbeda secara statistik sehingga layak dibandingkan (Tabel 1).

Distribusi nilai SGA tidak berbeda secara signifikan antara kelompok COT sedang dan berat dari hari ke-1 hingga hari ke-5 $(\mathrm{p}>0,05)$.

Tabel 1. Karakteristik Subjek Penelitian

\begin{tabular}{llll}
\hline \multicolumn{2}{l}{ Cedera Otak Traumatik } & Nilai P \\
Variabel & Sedang & Berat & 0,652 \\
\hline Usia & & & \\
Mean \pm Std & $32,72 \pm 15,919$ & $30,27 \pm 17,550$ & 0,133 \\
BMI & & & \\
Mean \pm Std & $21,60 \pm 1,832$ & $19,80 \pm 3,364$ & 0,993 \\
Diagnosa & & & \\
EDH & $7(7 / 11)$ & $5(5 / 11)$ & \\
EDH dan ICH & $1(1 / 11)$ & $1(1 / 11)$ & \\
ICH & $1(1 / 11)$ & $1(1 / 11)$ & \\
SAB dan SBF & $0(0 / 11)$ & $1(1 / 11)$ & \\
SDH & $2(2 / 11)$ & $3(3 / 11)$ & \\
\hline
\end{tabular}

Keterangan: Untuk data numerik nilai $\mathrm{p}$ diuji dengan uji T tidak berpasangan apabila data berdsitribusi normal dengan alternatif Uji Mann Whitney apabila data tidak berdistribusi normal. Data kategorik nilai $p$ dihitung berdasarkan Uji Chi-Square dengan alternative Uji Kolmogorov Smirnov dan Exact Fisher apabila syarat dari Chi-Square tidak terpenuhi.Nilai kemaknaan berdasarkan nilai $p<0,05$. Tanda* menunjukkan nilai $\mathrm{p}<0,05$ artinya signifkan atau bermakna secara statistik. EDH: Epidural hematoma; ICH: intracranial hematoma; SDH: Subdural hematoma; SAB: Subarachnoid bleeding; SBF: Skull base fractures 
Tabel 2. Perbandingan SGA Hari ke-1 sampai Hari ke-7 pada Kelompok Cedera Otak Traumatik Sedang dan Berat

\begin{tabular}{|c|c|c|c|}
\hline \multirow[b]{2}{*}{ SGA } & \multicolumn{2}{|c|}{ Cedera Otak Traumatik } & \multirow[t]{2}{*}{ Nilai $P$} \\
\hline & $\begin{array}{l}\text { Sedang } \\
\mathrm{N}=11\end{array}$ & $\begin{array}{l}\text { Berat } \\
N=11\end{array}$ & \\
\hline SGA hari Ke-1 & & & 1,000 \\
\hline A & $0(0 / 11)$ & $0(0 / 11)$ & \\
\hline B & $11(11 / 11)$ & $11(11 / 11)$ & \\
\hline $\mathrm{C}$ & $0(0 / 11)$ & $0(0 / 11)$ & \\
\hline SGA hari ke-2 & & & 1,000 \\
\hline A & $0(0 / 11)$ & $0(0 / 11)$ & \\
\hline B & $11(11 / 11)$ & $11(11 / 11)$ & \\
\hline $\mathrm{C}$ & $0(0 / 11)$ & $0(0 / 11)$ & \\
\hline SGA hari ke-3 & & & 0,476 \\
\hline A & $0(0 / 11)$ & $0(0 / 11)$ & \\
\hline B & $11(11 / 11)$ & $9(9 / 11)$ & \\
\hline $\mathrm{C}$ & $0(0 / 11)$ & $2(2 / 11)$ & \\
\hline SGA hari ke-4 & & & 0,206 \\
\hline A & $2(2 / 11)$ & $0(0 / 11)$ & \\
\hline B & $8(8 / 11)$ & $6(6 / 11)$ & \\
\hline $\mathrm{C}$ & $0(0 / 11)$ & $5(5 / 11)$ & \\
\hline SGA hari ke-5 & & & 0,206 \\
\hline A & $3(3 / 11)$ & $0(0 / 11)$ & \\
\hline B & $8(8 / 11)$ & $6(6 / 11)$ & \\
\hline $\mathrm{C}$ & $0(0 / 11)$ & $5(5 / 11)$ & \\
\hline SGA hari ke-6 & & & $0,001^{* *}$ \\
\hline A & $9(9 / 11)$ & $0(0 / 11)$ & \\
\hline B & $2(2 / 11)$ & $6(6 / 11)$ & \\
\hline $\mathrm{C}$ & $0(0 / 11)$ & $5(5 / 11)$ & \\
\hline SGA hari ke-7 & & & $0,000^{* *}$ \\
\hline A & $10(10 / 11)$ & $0(0 / 11)$ & \\
\hline B & $1(1 / 11)$ & $6(6 / 11)$ & \\
\hline $\mathrm{C}$ & $0(0 / 11)$ & $5(5 / 11)$ & \\
\hline
\end{tabular}

Keterangan: SGAA: normal, SGA B: cukup/curiga malnutrisi, SGA C: malnutrisi berat. Untuk Data kategorik nilai p dihitung berdasarkan Uji Chi-Square dengan alternatif Uji Kolmogorov Smirnov dan Exact Fisher apabila syarat dari Chi-Square tidak terpenuhi. Nilai kemaknaan berdasarkan nilai $\mathrm{p}<0,05$. Tanda* menunjukkan nilai $\mathrm{p}<0,05$ artinya signifikan atau bermakna secara statistik.

Namun perubahan distribusi nilai SGA terjadi secara signifikan pada hari ke-6 dan hari ke-7, SGA yang lebih rendah (kelompok malnutrisi berat) didapatkan lebih banyak pada kelompok COT berat secara signifikan pada hari ke-6 dan ke
-7 ( $<<0,05$; Tabel 2). Pasien dengan COT sedang memiliki delta penurunan berat badan yang lebih kecil dibandingkan dengan pasien dengan COT berat dengan perbedaan yang signifikan $(\mathrm{p}<0,05$; Tabel 3). 
Tabel 3. Perbandingan Delta Penurunan Berat Badan Hari ke-1 sampai Hari ke-7 antara Kelompok Cedera Otak Traumatik Sedang dan Berat

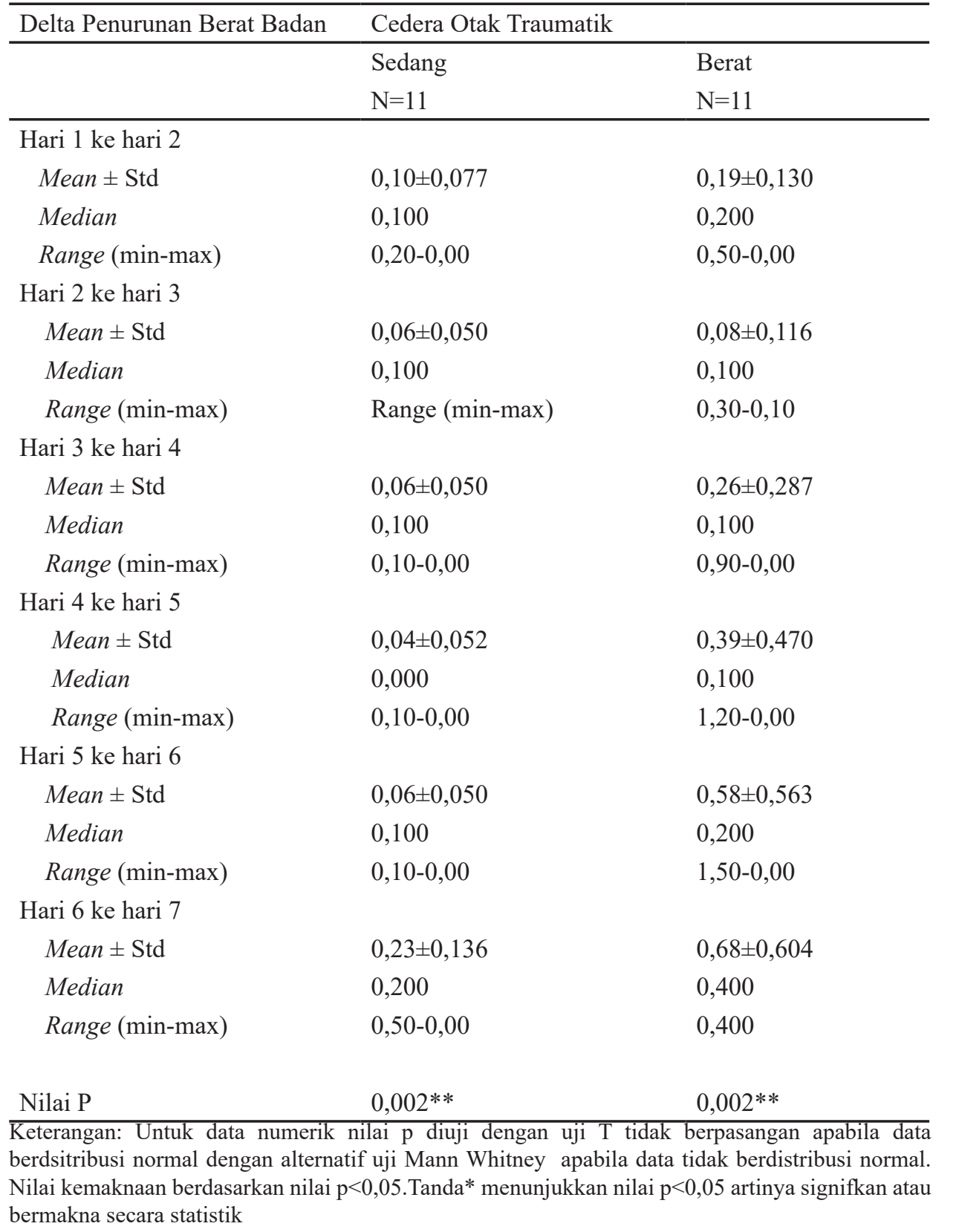

\section{Pembahasan}

Pada penelitian ini dilakukan penilaian SGA pada pasien COT sedang dan COT berat yang dirawat di RSUP Dr. Hasan Sadikin Bandung. Penelitian ini menunjukkan bahwa jumlah pasien yang mengalami malnutrisi berat mulai didapatkan pada hari ke-3 dan bertambah setiap harinya hingga signifikan secara statistik dibandingkan dengan pasien dengan COT sedang dan COT berat pada hari perawatan ke- 6 dan ke- 7 dengan p 0,001 dan 0,000 berturut-turut. Hal ini sesuai dengan penelitian sebelumnya di India terhadap 88 pasien dengan COT berat (GCS $<8)$ menggambarkan peningkatan progresif prevalensi malnutrisi pada pasien yang dirawat dengan COT berat. ${ }^{10}$ Pada kelompok COT sedang, pada penelitian ini didapatkan pada hari 


\section{Subjective Global Assessment Form}

\section{MEDICAL HISTORY}

Paitert name:

Dale:

\section{NUTRIENT INTAKE}

\section{1. $\square$ No change; adequate}

2. Inadequate; durition of insogequate intake

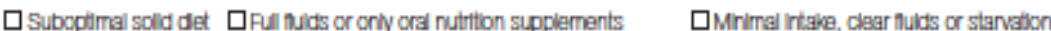

3. Nutrient Intake in past 2 weeks*

口Adequate

Dmproved but not adequaste DNo mprovement or hadequate

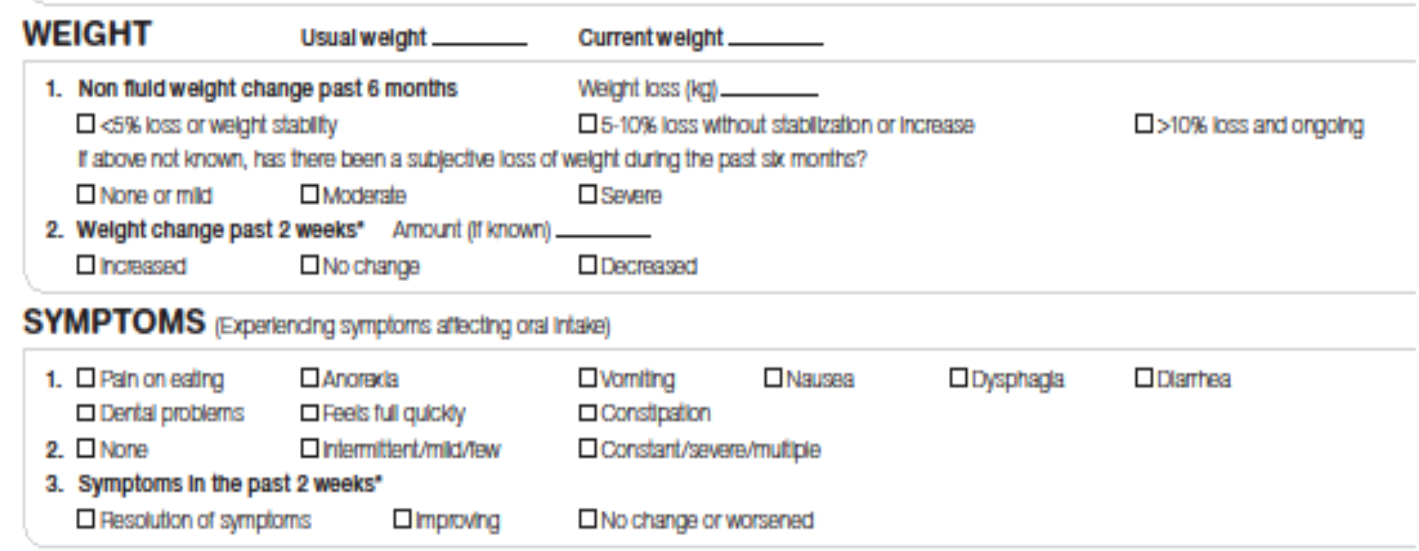

\section{FUNCTIONAL CAPACITY (Fatgue and progressive bss of function)}

\section{No dystunction}

2. Reduced capacty, duration de change

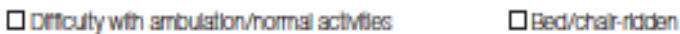

3. Functional Capacity in the past 2 weeks*
amproved
$\square$ No change
口Decrease

\section{METABOLIC REQUIREMENT}

\begin{tabular}{|c|c|c|c|}
\hline Hgh matabollc requiremert. & $\square$ No & 口Yes & \\
\hline & \multicolumn{3}{|c|}{ PHYSICAL EXAMINATION } \\
\hline Loss of bocty tat & 口No & $\square \mathrm{Mid} / \mathrm{M}$ oderste & 口severe \\
\hline Loss of muscle mass & 口No & 口Mid/Moderate & 口Severe \\
\hline Presence of edema/ascites & 口No & DMld/Moderste & DSevere \\
\hline
\end{tabular}

\section{SGA RATING}
口A Wel-nourished
口B Mldy/modaralaly mainourished Some progressive nutritional loss
口C Severely mainourtshed
Evdance of wasting and progressive symptoms

\section{CONTRIBUTING FACTOR}

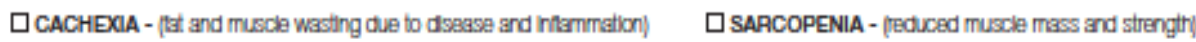




\section{Subjective Global Assessment Guidance For Body Composition}

\section{SUBCUTANEOUS FAT}

\begin{tabular}{|c|c|c|c|}
\hline Physical examination & Normal & Mild/Moderate & Severe \\
\hline Under the eyes & Sightly bulging area & $\begin{array}{l}\text { Somewhat hollow look, Sightly } \\
\text { dark cricles, }\end{array}$ & $\begin{array}{c}\text { Hollowed bok, depression, dark } \\
\text { cricles }\end{array}$ \\
\hline Trioeps & Large space between frngers & $\begin{array}{l}\text { Some depth to fat fissue, but not } \\
\text { ample. Loose fitting skin. }\end{array}$ & $\begin{array}{c}\text { Very Iittle space between fringers, } \\
\text { or ingers touch }\end{array}$ \\
\hline Rlbs, lower back, sides of trunk & $\begin{array}{l}\text { Chest is ful; ribs do not show. } \\
\text { Slight to no protrusion of the ilac } \\
\text { crest. }\end{array}$ & $\begin{array}{l}\text { Fibs obvious, but indentations are } \\
\text { not marked. liac Crest somewhat } \\
\text { prominent }\end{array}$ & $\begin{array}{l}\text { Indentation between ribs very } \\
\text { obvious. Ilac crest very prominent }\end{array}$ \\
\hline
\end{tabular}

MUSCLE WASTING

\begin{tabular}{|c|c|c|c|}
\hline Physical examination & Normal & Mild/Moderate & Severe \\
\hline Ternple & Wel-deíned muscle & Slight depression & Hollowing, depression \\
\hline Clavicle & $\begin{array}{l}\text { Not visble in males; may be } \\
\text { visible but not prominent in } \\
\text { fernales }\end{array}$ & $\begin{array}{c}\text { Some protrusion; may not be all } \\
\text { the way along }\end{array}$ & Protruding/prominent bone \\
\hline Shoulder & Rounded & $\begin{array}{l}\text { No square look; acromion } \\
\text { process may protrude sightly }\end{array}$ & Square look, bones prominent \\
\hline Scapula/ribs & $\begin{array}{l}\text { Bones not prominent, no } \\
\text { significarnt depressions }\end{array}$ & $\begin{array}{l}\text { Mid depressions or bone may } \\
\text { show slightly; not all areas }\end{array}$ & $\begin{array}{c}\text { Bones prominent; sigrifcant } \\
\text { depressions }\end{array}$ \\
\hline Quadriceps & Wel defined & Depression/atrophy medialy & $\begin{array}{l}\text { Prominent knee, Severe } \\
\text { depression medialy }\end{array}$ \\
\hline $\begin{array}{l}\text { Intercsesous muscle between } \\
\text { thumb and forefinger (back of } \\
\text { hand)" }\end{array}$ & $\begin{array}{l}\text { Muscle protrudes; could be fat in } \\
\text { fernales }\end{array}$ & Sightly depressed & Flat or depressed area \\
\hline
\end{tabular}

\section{FLUID RETENTION}

\begin{tabular}{|l|c|c|c|}
\hline Physical examination & Normal & Mild/Moderate & Severe \\
\hline Edema & None & $\begin{array}{c}\text { Pitting edema of extremities / } \\
\text { pitting to lvees, possble sacral } \\
\text { edema if bedridden }\end{array}$ & $\begin{array}{c}\text { Pitting beyond knees, sacral } \\
\text { ederna if bedridden, may also } \\
\text { have generalized ederna }\end{array}$ \\
\hline Ascites & Absent & & Present (may only be present on imaging) \\
\hline
\end{tabular}

A - Well-nourished no decrease in food/nutrient intake; < $5 \%$ weight loss; no/minimal symploms affecting food intake; no deficit in function; no deficit in fat or muscle mass OR "an individual with criteria for SGA B or C but with recent adequate food irtake; non-fluid weight gain; significant recent improvement in symploms alowing adequate oral intake; significant recent improvement in function; and chronic deficit in tat and muscle mass but with recent cirical improvement in function.

B - Mildly/moderately malnourished definte decregse in food/nutrient intake; $5 \%$ - $10 \%$ weight loss without stabilzafion or ogin; mild/scrne symptorns affecting food intake; moderate functional deficit or recent deterioration; mild/moderate loss of fat and/or muscle mass OR "an individual meeting criteria for SGA C but with improvement (but not adequate) of oral intake, recent stabilization of weight, decrease in symptoms affecting oral intake, and stabilization of functional status.

C - Severely malnourished severe deficit in food/nutrient intake; > 10\% weight loss which is ongoing; signifcart symptorns alfecting food/ nutrient intakersevere functional deficit OR "recent significant dekerioration obvious signs of fat and/or muscle loss.

Cachexia - If there is an underlying predisposing disorder (eg. maignancy) and there is evidence of reduced muscle and fat and no or limited improvernent with optimal nutrient intake, this is consistent with cachexia.

Sarcopenia - If there is an undertying disorder (e.g. aging) and there is evidence of reduced muscle and strength and no or limited improvernent with optimal nutrient intake. 
ke-4 jumlah pasien yang dikelompokkan menjadi SGA A (ternutrisi baik) bertambah, dan jumlah pasien yang dikelompokkan menjadi SGA B (ternutrisi cukup/curiga malnutrisi) berkurang. Hal ini menandakan perbaikan nutrisi pada kelompok COT sedang. Pemberian nutrisi pada pasien dengan COT sedang tidak mengalami masalah. Hal ini sesuai dengan rekomendasi yang menyarankan pasien harus diberikan nutrisi penuh dalam 7 hari setelah trauma. ${ }^{1-3}$ Pemberian nutrisi harus dimulai sejak dini dalam 24-48 jam dan berdasarkan kebutuhan nutrisi pasien tersebut selama 48-72 jam berikutnya. Proses ini terkadang menjadi tantangan pada pasien dengan COT berat karena pada COT berat dapat terjadi atoni gaster, ileus, dan ulkus yang disebabkan oleh stress. $^{2}$

Pasien dengan COT mengalami peningkatan respon stress yang ditandai dengan peningkatan katekolamin serta mediator inflamasi lainnya.3 Stimulasi simpatoadrenal akibat trauma mengakibatkan pelepasan katekolamin yang memegang perananpentingpadaregulasiresistensi pembuluh darah arteri dan kapasitansi pembuluh darah vena. Katekolamin mengakibatkan konstriksi pada pembuluh darah arterial dan vena pada sistem splanchnic. ${ }^{11}$ Skor GCS yang rendah berhubungan dengan makin meningkatnya kadar katekolamin yang dilepaskan. Pada beberapa penelitian, hiperaktivitas simpatis terjadi setelah COT berat. ${ }^{12,13}$ Semakin tinggi katekolamin yang dilepaskan, semakin rendah perfusi pada sistem gastrointestinal sehingga terjadi disfungsi gastrointestinal. ${ }^{14}$ Disfungsi gastrointestinal pasien COT sedang dan berat mengakibatkan jumlah volume residu gaster yang lebih tinggi sehingga pemberian nutrisi enteral sulit dilakukan. ${ }^{15,16}$

Pemberian nutrisi enteral pada penelitian ini diberikan pada hari ke-2 sesuai dengan panduan pemberian nutrisi pada pasien COT, namun pada beberapa pasien di kelompok COT berat terjadi gangguan pengosongan lambung sehingga pasien kembali dipuasakan ataupun dikurangi jumlah pemberian nutrisinya. ${ }^{6} \mathrm{Hal}$ ini merupakan salah satu faktor yang menyebabkan malnutrisi pada kelompok COT berat. Salah satu tanda malnutrisi adalah penurunan berat badan. Penelitian ini terjadi penurunan berat badan $>10 \%$ pada pasien dengan COT terutama pada COT berat pada hari ke-6 dan ke-7 sehingga pada hari tersebut lebih banyak pasien COT berat yang dikelompokkan menjadi kelompok C (malnutrisi berat). Penelitian ini sesuai dengan literatur yang menyatakan terjadi kehilangan berat badan $15 \%$ perminggu pada pasien COT. ${ }^{6}$ Tabel 3 membuktikan bahwa terdapat perbedaan berat badan yang signifikan setiap harinya pada kelompok COT sedang dan COT berat. Selain itu perubahan berat badan yang signifikan terjadi setiap harinya pada kelompok COT berat $(\mathrm{p}<0,05)$ sehingga menguatkan bukti bahwa malnutrisi terjadi pada kelompok COT berat. Malnutrisi yang terjadi pada pasien dengan COT berat dapat disebabkan oleh berbagai faktor, yaitu hiperkatabolisme yang terjadi pada pasien COT berat, perlambatan pemberian nutrisi enteral akibat disfungsi gastrointestinal pasca COT, pemberian protein yang kurang, ataupun kadar albumin yang rendah. ${ }^{1,2,6,10,17}$

Pada penelitian sebelumnya juga dikatakan bahwa bila disertai dengan imobilitas, hiperkatabolisme akan meningkatkan risiko malnutrisi. Hal ini sesuai dengan penelitian ini, dimana pasien dengan COT berat sebagian besar terhubung dengan ventilator dan imobile akibat sedasi yang diberikan ataupun GCS yang rendah dan kondisi pasien bertambah buruk. ${ }^{7}$ Seperti yang telah dikemukakan sebelumnya, pada penelitian ini pemberian nutrisi enteral pada kedua kelompok COT dimulai sejak hari perawatan ke2. Namun pada pasien dengan COT berat terjadi perlambatan pengosongan lambung, sehingga pada beberapa pasien terdapat penundaan nutrisi dan juga pengurangan jumlah nutrisi yang diberikan. Jumlah protein yang diberikan pada setiap pasien telah dihitung oleh nutrisionis dengan mempertimbangkan hiperkatabolisme yang terjadi pada pasien dengan COT terutama COT berat, namun akibat pemberian nutrisi enteral yang terhambat, asupan protein yang diberikan pun akan berkurang. Kadar albumin pada setiap pasien pada penelitian ini tidak diukur, namun, dapat dianggap normal karena semua pasien memiliki BMI yang normal pada semua kelompok. 


\section{Simpulan}

Pasien COT berat memiliki status nutrisi yang lebih buruk dibandingkan pasien COT sedang, disebabkan penundaan pemberian nutrisi ataupun pengurangan jumlah nutrisi karena gangguan pengosongan lambung yang terjadi pasca COT akibat kondisi pasien yg memburuk. Malnutrisi berat mulai terjadi pada kelompok COT berat dari hari perawatan ke-3. Pada kelompok COT sedang terjadi perbaikan nutrisi yang mulai terjadi pada hari ke-4. Pasien dengan COT berat mengalami penurunan berat badan yang signifikan setiap harinya dari hari ke-1 hingga hari ke-7 perawatan. Hasil penelitian ini diharapkan dapat memberikan informasi mengenai status gizi dan malnutrisi yang terjadi pada pasien COT, terutama COT berat serta dapat digunakan untuk data penelitian selanjutnya serta bermanfaat untuk menentukan strategi pemberian nutrisi pada pasien dengan COT berat sehingga dapat mengurangi angka terjadinya malnutrisi.

\section{Daftar Pustaka}

1. Hartl R, Gerber L, Ni Q, Ghajar J. Effect of early nutrition on deaths due to severe traumatic brain injury. J Neurosurg. 2008;109(1):50-6.

2. Stutz HR, Charchaflieh J. Postoperative and intensive care including head injury and multisystem sequelae. Dalam: Cottrell JE, Young WL, penyunting. Cottrell and Young's Neuroanesthesia. Edisi ke-5. Philadelphia: Mosby Elsevier; 2010, 407-8.

3. Campos BBNdS, Machado FS. Nutrition therapy in severe head trauma patients. Rev Bras Ter Intensiva. 2012;24(1):97-105.

4. Peetz A, Mogensen K, Rawn J, Salim A, Christopher K. Traumatic brain injury, nutritional status and outcomes: a registry based cohort study. Intens Care Med Experiment. 2015;3(Suppl 1):A437.

5. Wang X, Dong Y, Han X, Qi X-Q, Huang C-G, Hou L-J. Nutritional support for patients sustaining traumatic brain injury: a systematic review and meta-analysis of prospective studies. PLOS ONE. 2013;8(3):e58838.

6. Bisri T. Terapi nutrisi pada pasien cedera kepala berat. Penanganan Neuroanestesia dan Critical Care Cedera Otak Traumatik. Edisi. Bandung: Fakultas Kedokteran Universitas Padjadjaran; 2011, 229-4.

7. Costello L, Lithander F, Gruen R, William L. Nutrition therapy in the optimisation of health outcomes in adult patients with moderate to severe traumatic brain injury: findings from a scoping review. Injury. 2014;45(12):1834-4.

8. Azim A, Ahmed A. Nutrition in neurocritical care. Neurol India. 2016;64(1):105-14.

9. Fink JdS, Mello PDd, Mello EDd. Subjective global assessment of nutritional status : a systematic review of the literature. Clin Nutr. 2015;XXX:1-8.

10. Dhandapani S, Manju D, Sharma B, Mahapatra A. Clinical malnutrition in severe traumatic brain injury: factors associated and outcome at 6 months. Indian J Neurotrauma. 2007;4(1):35-9.

11. Gelman S, Mushlin PS. Catecholamineinduced changes in the splanchnic circulation affecting systemic hemodynamics. Anesthesiology. 2004;100(1):434-9.

12. Choi HA, Jeon S-B, Samuel S, Allison T, Lee K. Paroxysmal sympathetic hyperactivity after acute brain injury. Curr Neurol Neurosci Rep. 2013;13(1):370-80.

13. Fernandez-Ortega JF, Baguley IJ, Gates TA, Garcia-Caballero M, Quesada-Garcia JG, Prieto-Palomino MA. Catecholamines and paroxysmal sympathetic hyperactivity after traumatic brain injury. J Neurotrauma. 2017;34(1):109-14.

14. Takala J. Determinants of splanchnic blood flow. Br J Anaesth. 1997;77(1):50-8. 
15. Blaser AR, Malbrain MLNG, Starkopf J, Fruhwald S, Jakob SM, Waele JD, dkk. Gastrointestinal function in intensive care patients: terminology, definition, and management. Recommendation of the ESICM Working Group on Abdominal Problems. J Intensive Care Med. 2012;38(1):384-94.
16. Hurt RT, McClave SA. Gastric residual volumes in critical illness: what do they really mean? Crit Care Clin. 2010;26(1):481-90.

17. Kao C-H, Lai S-PC, Chieng P-U, Yen T-C. Gastric emptying in head-injured patients. Am J Gastroenterol. 1998;93(7):1108-12. 